\title{
Closing Digital Divides: The United States' Policies
}

\author{
SongPhan CHOEMPRAYONG \\ School of Information and Library Science, University of North Carolina at Chapel Hill, Chapel Hill, NC, USA
}

Since the emergence of information technology, the gap between information 'haves' and 'have-nots' has been broadening: the information rich become richer, while the information poor are poorer. This situation contributes to various issues related to individuals and society. Interestingly enough, although the United States is one of the leading countries in the information and communication technology (ICT) field, according to many studies, the digital divide still exists in many layers and from different perspectives. This paper critically discusses how the US anticipates these issues as well as how national information policy is emerging to close the digital divide.

\section{Digital divide: definitions and scope}

The power of information technology has been significantly stronger due to its increased presence everywhere. The benefits of information technology have been exposed in various ways. The explosive growth of telecommunications, particularly the Internet, not only virtually eliminates physical distances, but also extensively delivers a great deal of information to individuals and societies. However, there are concerns from a democratic point of view about the inequality of opportunities to obtain the benefits from the use of information technology.

The term digital divide has been increasingly used to describe this gap in discussions among different groups of scholars and professions. The definition of the term, laying out the scope of the issue, has been discussed widely. Compaine (2001) introduces the digital divide as "the perceived gap between those who have access to the latest information technologies and those who do not." Compaine addresses the moving boundaries of the issue from personal computer ownership to incorporate Internet access, and recently to high-speed (broadband) access. Nevertheless, according to his definition, the term latest information technologies may raise some definitive questions. For example, is the digital divide the matter of not obtaining the latest technologies or a sufficient subset of recent technologies? Are the latest technologies always categorized as being in the interest of public good?

From the political point of view, Norris (2001) elaborates the problem in three aspects: global divide, social divide and democratic divide. Her definition focuses on those gaps of Internet access only covering international and domestic levels, and finally narrows down to individual engagement, mobilization and participation. However, the scope of the issue is expanding continually due to the development of technology. Mossberger, Tolbert and Stanbury (2003) argue that the restriction of digital divide to the problem of access to technology is insufficient. They broaden the scope of the issue to include four major aspects: access, skills, economic opportunity and democratic divides. This paper uses these four categories to frame the movements of the United States in closing the digital divide. However, it seems likely that there is no consensus on the boundaries of this issue. While society and technology have been continu-

Songphan Choemprayong is currently a doctoral student at the School of Information and Library Science, University of North Carolina at Chapel Hill, Chapel Hill, NC, USA. Address: 100 Manning Hall CB\#3360, Chapel Hill, NC 27514-3360, U.S.A. E-mail: songphan@unc.edu

This paper was written when the author was enrolled in the MLIS program at the School of Information Sciences, University of Pittsburgh in December 2004 for the Information Policy class taught by Dr. Toni Carbo. 
ally growing, the boundaries of the digital divide still remain unclear.

\section{Stakes and stakeholders}

To understand the overall concept of the digital divide, it is useful to address the stakeholders as entities. Then, we would be able to map the relationships among these stakeholders. Below are listed five major stakeholders who may obtain advantages and/or disadvantages from closing the digital divide.

\section{Individuals}

Access to the information available from cyberspace is crucial for different purposes to different people, in particular economic and social benefits. Such information can be used in routine everyday life for education, business transactions, personal communication, information gathering, job searches and career development. By closing the digital divide, people would be given equal opportunity to communicate and support their quality of life. This also includes the opportunity to participate in civic activities. In terms of economic benefits, individuals could be considered as consumer and end user groups who have direct effect from these efforts. In particular, products and services related to information and communications technology have been decreasing in price over time. Thus consumers, particularly low-income groups, could have more opportunity to own and access electronic and online information.

\section{Government}

The existence of the digital divide may affect the quality of life of citizens in terms of their ability to compete. In particular, if we consider economic competitiveness, digital literacy could greatly contribute to the potential growth of a nation's economy. A government also plays a leading role in promoting participation from society, from both the public and private sectors. Moreover, a government itself may have to invest to establish and maintain an information infrastructure. Many government units are directly responsible for developing policies in this area, including the Department of Education, Department of Commerce, Office of Management and Budget (OMB), Federal Com- munications Commission (FCC) and Department of Health and Human Services Administration on Aging. Moreover, as an indirect benefit, providing an opportunity for Internet access may also lead to political support.

\section{Businesses}

Businesses, such as hardware manufacturers, software developers, Internet Service Providers, telecommunications companies as well as content developers, rely on the consumption of computer and Internet services. Closing the digital divide may result in a higher rate of service consumption as well as higher competitiveness. The efforts to close the digital divides also contribute to flow of economy at the national and international level. Companies such as banks, insurance companies, electric companies, retail businesses and transportation businesses may gain from the development of policies regarding the digital divide.

\section{Public access providers}

In addition to access from home, public access is another major gateway to computers and the Internet. These providers include schools, libraries, Internet cafes, public places and public access programs (e.g., Community Technology Centers). Support for these providers is not only beneficial financially, but also could be an opportunity for staff career development.

\section{Society}

Internet access clearly provides a great deal of benefit to society, particularly, in terms of culture. In a powerful information society, communication patterns, flow of information, social norms and practices could be exchanged and transferred effectively. Moreover, the equality of opportunity has significant value in a democratic society.

\section{The digital divide in the United States}

Although the United States is recognized as a leading high-technology country, many studies indicate the existence of a digital divide from various perspectives. In 1995, the National Telecommunications and Information Administration (NTIA) 
within the Department of Commerce conducted their first survey to address the have and have-not issues based on the U.S. Census Bureau's Current Population Survey (CPS) (NTIA 1995). This study later became the first study in the series entitled "Falling Through The Net," now containing four more studies (NTIA 1998, 1999, 2000, 2002). The series focuses on the disparities between 'haves' and 'have-nots' based on socio-economic factors such as age, race and ethnicity, geographical location, income and household type. The reports also document the increasing number of Internet users. The studies evolved from studying hardware ownership to looking at Internet access, and eventually to the characteristics of Internet use.

The study in 2000, in addition to measuring the digital divide by looking at the differences in the usage share of each group, includes data on high-speed access, as well as access by disabled groups. Significantly enough, the study found an increase in numbers of Internet using individuals, from $32.7 \%$ in 1999 to $44.4 \%$ in 2000 . Nevertheless, while the total gap between households had significantly narrowed, the divide still remains or has slightly expanded "between those with different levels of income and education, different racial and ethnic groups, old and young, single and dual-parent families, and those with and without disabilities." (NTIA 2000, xvi)

The latest study in 2002, A Nation Online, addresses the persistent digital divide based on demographics as well as disability. The study found the disappearance of differences between urban and rural area groups. However, the study apparently focuses on Internet use rather than Internet access.

There is another set of studies conducted by the Pew Internet $\mathcal{E}$ American Life Project focusing on various aspects of Internet access and usage. There are numerous studies addressing Internet use by different demographic groups, such as age (Fox 2001; Fox 2001; Madden \& Rainie 2003; Lenhart, Rainie \& Lewis 2001; Lenhart 2000), race (Spooner 2001; Spooner 2000; Rainie 2001), and location (Harwood \& Rainie 2004; Bell, Reddy \& Rainie 2004; Spooner 2003). These studies illustrate the existence of the digital divide in U.S. society.

In particular, the study by Lenhart et al. (2003) monitors the movement of non-Internet users. The finding addresses three different kinds of non-Internet users including Net-Evader, Net-Dropout and Truly Disconnected. The study does not consider only physical aspects, but also social factors. Although most non-users live close to the Internet, both at home or outside, there are also social differences between Internet users and non-users. Significantly enough, the majority of non-users do not plan to use the Internet. Moreover, the study also re-confirms the existence of the digital divide based on demographic disparities.

In academic settings, Hoffman, Novak and Schlosser (2000) conducted a research study measuring the factors of disparities in access. They reemphasized the impact of demographic factors, including race, income and education, in expanding gaps in Internet access.

The recent study conducted by Mossberger, Tolbert and Stansbury (2003) expands the scope of digital divide focusing on four aspects instead of merely the issue of access. In terms of the access divide, the study re-asserts the existence of access gaps in relation to demographic, in particular lowincome, geographical, and political factors. They found a positive relationship between people who use Internet at home and outside addressing that "in fact those lacking a home connection are less likely to use the Internet in other places such as libraries." $(2003,33)$

For the skill divide, two important distinct concepts are incorporated: technical competencies and information literacy. The study also identified the need to be assisted as well as instructional preferences. The results replicate the skill divide and access divide in terms of demographic factors. In addition, it shows that those sampled are likely to prefer self-help in the form of online instruction, tutorials or manuals instead of personal instruction or classes. This finding provides some implications for those points of access such as schools and libraries.

To examine the economic opportunity divide, the study focuses on two major components: online job searching, and online courses. The results demonstrate the close relationship between computer skills and economic opportunity. Moreover, among those who are convinced to search for a job or take courses online, many of them are digitalliterate. However, the study apparently collected only the attitude of respondents, not the actual context and situation. The data from the providers' sides need to be addressed as well. Holzer (1996) discusses how daily computer use is required for 
different jobs. In particular, $75 \%$ of jobs for college graduates require daily computer use.

The last category, the democratic divide, consists of readiness, including attitudes and experiences, regarding Internet use for political participation and information gathering. The findings show that many Americans are hesitant about the use of the Internet in political participation, especially online voting. It also expresses that those who have higher education and income are more likely to support and participate in digital democracy and electronic government.

To close the digital divide, the United States has developed policies at different levels of governments. The efforts also include public and private sector participation. Policies have been developed within the framework of three major components: Information Infrastructure, Digital Literacy, and Digital Society. In each component, the roles of stakeholder are distinctive according to the context of the development of policy.

\section{Constructing the information infrastructure}

The notion of Information Infrastructure was first mentioned during the time of President Clinton. In 1993, the U.S. Advisory Council on the National Information Infrastructure was established. A report, A Nation of Opportunity, lays out a plan for Americans to encounter the information revolution. Focusing on the Information Superhighway, the Council outlined the fundamental goals and visions in conjunction with the prospective critical issues. Also, the recommendations are discussed in terms of impact on key areas, ensuring access for all, major policy issues and ethical concerns, and key roles in society. In particular, the concern about disparities in access - at that time, the Internet was not in the mainstream of information transfer - was mentioned in three major areas including 1) Information Superhighway deployment (removing regulatory disincentives and promoting neutrally competitiveness), 2) Universal access and service (providing "affordable, ubiquitous, convenient, and functional access," providing opportunities to producers of information for individuals as well as facilitating disabled individuals), and 3) Government's role in leading and protecting the existence of information and services. (U.S. Advisory Council on the National Information Infrastructure 1996, 11)

\section{Hardware and software}

The focus on the digital divide began with concerns about hardware and software ownership, particularly in households. In 1995, Vice President $\mathrm{Al}$ Gore announced the development of a National Information Infrastructure as a priority of the Clinton administration. In 2000, President Clinton proposed $\$ 2.25$ billion worth of initiatives to bridge the digital divide including allocation to encourage private sector donation of computers, sponsorship of community technology centers and technology training for workers. Within the initiative, public and private partnerships were supported to expand home access to computers and the Internet for low-income families as well as to deploy broadband networks in under-served areas. Moreover, \$45 million was allocated to promote innovative applications of information and communications technology for under-served communities. (U.S. White House 2000; Lacey 2000)

However, the major efforts apparently come from public and private sectors. Large information technology businesses such as Hewlett-Packard, 3Com, Intel, Lucent Technology, and Microsoft have played major roles in providing computers and Internet access.

For instance, through the Gates Foundation, Microsoft has delivered financial support to public libraries initiating and sustaining access services. "Together with libraries, library supporters, Microsoft, and Gateway, the foundation completed its initial \$250 million commitment to install more than 47,000 computers and train librarians in nearly 11,000 libraries across all 50 states and the District of Columbia." (Gates Foundation 2003)

Cisco Systems Inc. started its Cisco Networking Academy in 1997 donating equipment, products and services to high schools and community centers in U.S. Empowerment Zones. The Academy also provides training programs.

Apart from corporate support, Computers for Youth (CFY), a non-profit organization, has been trying to bring affordable Internet access to the homes of minority children since 1999. It started to distribute PCs to schools in low-income public middle schools in the New York City area. In addition to home computers, the program promises to provide Internet access, training, technical support, email accounts, and tailored web content to students, parents and teachers. There are now 
more than 1,200 families and teachers being served each year. (Computers for Youth 2004)

There are numerous non-profit initiatives supporting hardware and software ownership. Many projects provide networking infrastructure beyond simple hardware.

\section{Networking and connectivity}

The concept of universal service in the Communications Act of 1934 became the Universal Service section in the 1996 Telecommunication Act. The principles of this section are originally to provide quality services in reasonable and affordable rates equitably and with nondiscriminatory contribution to all regions of the U.S. as well as emphasizing low-income and rural Americans and certain public providers.

In particular, section h-1-B introduces the regulations that facilitate such telecommunication services to elementary schools, secondary schools and libraries for educational purposes by providing for lower rates than those charged for similar services to other parties. Later, the Federal Communications Commission responded to that section by setting the maximum-price limitation and discount rates, commonly known as E-rate or Education Rate, in the Federal-State Joint Board on Universal Service in 1997. The E-Rate Ruling establishes a matrix for calculating individual discount rates for each eligible school and public library, based on economic status and geographic location. Eligible schools and libraries can earn discounts of twenty to ninety percent on telecommunication services, Internet access, and internal connections necessary for deploying technology for educational activities. The Universal Service Fund for schools and libraries has been in place since 1998.

In 2000, the Department of Education published a formative evaluation report of the first two years of the E-Rate program. The findings show that public schools have taken the most advantage of the program, granted nearly $\$ 4$ billion. Larger districts, schools and libraries were most likely to apply for discounts. Significantly enough, most funds were used for internal connections (58 percent), while only 8 percent was used for Internet access.

However, Cooper and Kimmelman (1999) argued that the overall Telecommunication Act of
1996, although it was intended to provide fairness in competition and remove monopolization, contributed to a digital divide. They asserted that the implementation of the Act unintentionally enhanced "the growth of a costly division between telecommunications 'haves' and 'have-nots.'" They recommended reconsidering the policy as follows: protecting consumers against the failure of competition, promoting effective competition (particularly supporting local markets) and preventing anticompetitive concentration (especially business merging).

Another contributing program was initiated by the National Science Foundation (NSF), called Advanced Networking with Minority-Serving Institutions. The goal of the project is to assist MinorityServing Institutions, such colleges or universities designated by the Department of Education "as they develop the campus infrastructure and national connections to become and remain full participants in the emerging Internet-based Information Age" (National Science Foundation 2004). The project began in 1999 when NSF awarded a four-year, \$6 million grant to EDUCAUSE, a nonprofit association with the mission of transforming higher education through information technology. The project focused on three educational communities: Hispanic-Serving Institutions (HSIs), Historically Black Colleges and Universities (HBCUs) and Tribal Colleges and Universities (TCUs). The major activities were the establishment of prototypes or experimental networks as well as regional network support centers. They also provided on-campus and online workshops and training programs. Moreover, they provided such services as campus visits to assess and consult the campus network and IT organizations, curriculum and faculty development, distance learning assistance, strategic planning, technical assistance, and wireless system implementation and consultation.

The impact of the digital divide was the unambiguous cause of the development of the Rural Utility Service program of the Department of Agriculture. The program expanded the scope of its contribution, from the earlier electricity, telephone, water and waste disposal services, to include broadband connection. Launched in January 2003, the Rural Broadband Loan and Loan Guarantee Program has been offered to facilitate the deployment of broadband services in rural communities. 


\section{Public access facilities}

As a part of the Information Infrastructure, schools and libraries, considered important means to access the Internet, have been enhanced strategically and technically. The E-Rate program is an obvious manifestation of how the U.S. government was aware of the importance of these public access providers' influence on the digital divide.

A number of studies have exposed how libraries, particularly public libraries, contribute to narrow the digital divide. According to Bertot and McClure (2002), 95 percent of public libraries in the United States provide free access to computers and the Internet, in particular in the poorest areas. A report published by collaborative organizations (e.g. American Library Association (ALA), Benton Foundation, Institute of Museum and Library Services (IMLS), Pew Internet \& American Life Project), Toward Equality of Access, summarizes the use of computers in libraries into four major aspects: contribution to disadvantaged groups; contribution to basic computer and Internet skills; contribution to daily basis activities including communication, learning, working, and creation; and contribution to rural communities. The report also identifies challenges for libraries to sustain their ability to provide public access including: hardware and software upgrades, Internet connectivity, keeping systems running, staff training and keeping libraries open.

However, to increase opportunities to access in outreach areas, public libraries may not cover all targeted areas. As a part of the proposal in 2000, President Clinton supported the establishment of Community Technology Centers, a program under the U.S. Department of Education's Office of Vocational and Adult Education. This federal program, through about 400 centers nationwide (Mossberger, Tolbert \& Stanbury 2003, 3) offers assistance including hardware, software, content development and training to disadvantaged communities. Panuel et al. (2000) evaluated 84 grantees of the program in the financial year 1999. The study found that the centers mainly served those groups least likely to have access to computers and the Internet, in particular African-American, Latino, Native Americans, and Alaskan Natives as well as unemployed groups. Various services have been offered such as open access to technology, technology skills programs (using software and the Internet), teaching technical or hardware skills, programs for developing job skills, and General Educational Development (GED) and English as a Second Language (ESL) programs.

However, there is apparently no formative report on the evaluation of the program. Such factors, in particular users and usages of the program, must be measured to assess the achievement of the program. Unfortunately, the Bush Administration has recently dismissed the program. The program was financially terminated in 2003 since it was claimed that according to the final NTIA report, A Nation Online, the number of people who have access to computers and the Internet has been increasing. Nonetheless, the differences in access based on socio-economic factors still persist.

Among many other pubic access initiatives, the Neighborhood Networks program was created in 1995 by the Department of Housing and Urban Development (HUD). The program aimed to establish multi-service community learning centers. The services offered are likely similar to the Community Technology Centers program providing computer access, advanced literacy programs, programs to prepare residents to take advantage of employment opportunities, and access to healthcare information and other social activities. There are currently more than 1,100 Neighborhood Networks centers across America, in both urban and rural areas.

\section{Promoting digital literacy}

The matter of individuals' skills is important to the digital divide. Without skills, having a computer and the Internet is nothing. A couple of studies (Hargittai 2002; Mossberger, Tolbert \& Stanbury 2003) indicate the presence of a skills divide. There are two key areas related to a skills divide: technical competency and information literacy. Mossberger, Tolbert and Stanbury $(2003,38)$ identified technical competency as "the skills needed to operate hardware and software," while information literacy is defined as "the ability to recognize when information can solve a problem or fill a need and to effectively employ information resources" (Association of College \& Research Libraries 1989). In the U.S., the movement to promote digital literacy, in particular information literacy, has been underway for years. Although many have argued that 
a skills divide has been dismissed by the government and in many studies, the remarks by Vice President Al Gore in the Digital Divide Event on April 1998 (U.S. White House 1998) encouraged developing the skills and confidence of young people. He introduced the concepts of online mentoring and tutoring, including a national network of online volunteers from companies, labor unions and scientific organizations.

In 1987, the American Library Association (1989) founded the Presidential Committee on Information Literacy to address information literacy in educational environment, design models for information literacy development, and determine implications for the continuing education and development of teachers. The committee published the report in 1989 examining the importance of information literacy, opportunities to develop information literacy and making recommendations in terms of institutional, professional and national perspectives. In 1999, the Association of College and Research Libraries (ACRL) endorsed the Information Literacy Competency Standards for Higher Education, introducing five key standard areas as well as performance indicators, and expected outcomes.

Additionally, significant progress was made with the Information Literacy Meeting of Experts conducted in September 2003 and sponsored by U.S. National Commission on Libraries and Information Science (NCLIS) and the National Forum on Information Literacy (NFIL) with the support of the United Nations Education, Scientific, and Cultural Organization (UNESCO). The meeting took a step in "defining the information literacy concept, identifying its role in transforming, and plans of action" (Thompson 2003, 3). The meeting also passed the Prague Declaration proposing basic Information Literacy principles.

Among other grant programs focusing on improving digital literacy, the Tomorrow's Teachers to Use Technology program was established by Department of Education in 1999. The program focuses on information technology skills of teachers in elementary and secondary schools. It supports different activities such as faculty development, course restructuring, certificate policy changes, and online teacher preparation. Until 2003, the program has granted nearly $\$ 400$ million, intentionally supporting the No Child Left Behind Act of 2001.

\section{Building digital society}

In addition to infrastructure and human resources aspects, society itself plays a large role in narrowing the disparity. Society should be determined in terms of contextual factors such as online content and services provided by government, and public and private organizations.

\section{Digital citizenship}

To sustain and empower democracy, information and communications technologies play roles in promoting people's participation and engagement. Online national voting was first launched in the U.S. in 2000. However, it is still a controversial topic and faces opposition. Many have concerns regarding security, integrity and reliability issues. A number of research studies have been conducted to find the resolution technically. However, many local private and public organizations have implemented electronic voting in their own organizational elections.

In addition to electronic voting, there are a number of pilot projects implementing digital citizen participation. The City of Berkeley, California, for instance, initiated a digital democracy program allowing the residents to register online their opinions about revisions to the city's general plan during the year 2000 (Mossberger, Tolbert \& Stansbury 2003, 106). However, participation seems to be less impressive given the small number of participants, including those who gave and rated comments and viewers. Eventually, the revision of the plan was based on comments by the city's staff, rather than participants. However, the study does not exactly show the factors/causes why the program was not successful. The argument that the digital divide totally affected the program may not entirely represent the situation. A comparative study of traditional and online participation in the same activity is needed to inform these findings.

E-Government is another effort promoted by the Clinton Administration. In the Bush Administration, three principles have been announced as guidelines for developing E-Government: citizencentered, results-oriented and market-based (Bush n.d.). The E-Government Act of 2002 was enacted to expand the E-Government initiative. However, in addition to sharing information between government units and providing equal opportunity 
of access, the Act seems to focus more on security issues. In particular, the Federal Information Security Management Act of 2002 responds to the Homeland Security Act. From the Paper Reduction Act and the first integrated government portal, Firstgov.gov, in the Clinton administration, the E-Government initiative now has shifted to more trusted and secured standard-based authentication systems introducing the E-Authentication initiative.

Another aspect that should be included as the foundation of the digital society is digital healthcare. In Universal Service, healthcare providers are one of the target groups of public access providers. Also the National Institute of Health (NIH) has provided financial support to research projects relevant to the implementation of information technology for medical records (National Library of Medicine 1994). There are also such health information services available publicly as the U.S. National Library of Medicine's PubMed Central (PMC). The National Library of Medicine (NLM) has also been an active leader in providing digital information, launching many projects and developing standards and policies responding to information issues such as copyright and privacy.

Furthermore, the digital economy could not be completed without e-commerce. According to the report of the Advisory Council on the National Information Infrastructure (1996), e-commerce is one of the key areas recommended for the Federal Government to consider, particularly in terms of legal, regulatory and policy issues. In 1998, Congress created the Advisory Commission on Electronic Commerce to study taxation and tariffs on transactions using the Internet and Internet access in different levels. The Commission published its report in 2000 covering six policy areas: sales and use taxes, business activity taxes, Internet access, taxation of telecommunication services and providers, international taxes and tariffs, and the need for improved knowledge of international ramifications.

The digital economy also includes a digital workforce. A study of the U.S. Department of Commerce (1999) points out some concerns about the lack of IT professionals in the labor market. The recommendations are introduced in response to digital inequality issues such as increasing and preparing young people to enter technical education and careers, and the participation of groups underrepresented in the technical professions. This is an advance step in closing the digital divide in the career and professional dimensions, beyond providing basic skills and training services.

\section{Providing digital opportunity}

From an optimistic perspective, the concept of the digital divide has been converted to digital opportunity. In 2000, two critical national goals were introduced: 1) ensuring access to $21^{\text {st }}$ Century learning tools for every child in every school and 2) expanding digital opportunity for every family and community (U.S. White House 2000). Internationally, the concept was adopted at the G-8 Okinawa Summit in 2000 into the Digital Opportunity Initiative supported by Accenture, the Markle Foundation and the United Nations Development Program (UNDP).

To expand digital opportunities, additional funding is necessary for the support and the development of digital society. Many programs have been launched to provide capital for national leadership, innovation and research toward the advancement of information technology in education and lifelong learning. The Technology Opportunities Program is one example of a grant-based initiative focusing on network technologies in communities. The program was under the supervision of NTIA. Unfortunately, the Bush Administration financially terminated the program. However, there are still many financial opportunities from many organizations, for instance National Science Foundation (NSF), Institute of Museum and Library Services (IMLS), and National Institutes of Health (NIH). Moreover, many public and private organizations are also active in improving quality of life through digital technologies. Such programs include the Digital Opportunity Investment Trust, LINCT coalition, Benton Foundation and many other non-profit organizations.

In particular, the Benton Foundation serves as a founder and coordinator of the Digital Divide Network "developing new, innovative digital divide strategies and for making current initiatives more strategic, more partner-based and more outcome-oriented, with less duplication of effort and more learning from each others' activities" (Digital Divide Network 2004). The network offers a wide range of information, tools and resources that help policy makers and practitioners to keep 
up-to-date with digital divide paradigm developments.

\section{Issues $\mathcal{E}$ recommendations}

Although the United States is considered to be at the forefront of closing the digital divide, there are some issues to be addressed in terms of policy development. Four major aspects should be investigated to develop effective short-term and longterm solutions.

\section{Sustainable support}

Most initiatives support public access within a limited amount of time. Further consideration must be given to the long-term strategic plan of how those access providers will become sustainable.

\section{Quality assurance}

Rather than focusing primarily on quantitative outcomes such as Internet consumption figures and economic indicators, the quality of services needs to be considered as well. Evaluation and assessment methodologies need to be discussed as well. If the concept of the digital divide is a matter of having the latest technologies, as Compaine's definition suggests, one should identify how to help those under-served groups to upgrade and improve the technology that they currently own. However, the position of the digital divide on a continuum between sufficiency and luxury may need to be identified as well. This would guide policy makers and practitioners to make better decisions.

In addition, social impact is another aspect that needs to be considered since the Internet could have both advantages and disadvantages. Sandvig (2001) found unexpected outcomes in the actual implementation of digital divide policy. The results indicated that the Internet appears to be used most often as an active medium of play and leisure. Children rarely used the facilities for educational and informational purposes, or even commercial business. Also, children are likely to learn how to use computers and the Internet from strangers by watching or asking questions. In addition, the privacy and indecency issues are important for attention. The digital divide seems to be inseparable from those other information is- sues. Therefore, the policy making process should consider such principles as intellectual property, privacy and indecency as well.

\section{Market issues}

It appears that most of the programs have concentrated on increasing public access, while few initiatives focus on household computers. In particular, the issue of equipment and software prices is of concern. Although desktop computer average prices have been falling significantly every year, from $\$ 844$ in 2001 to $\$ 610$ in 2004 (Spooner 2004), they continue to be a big investment for low-income households. In a free trade society, the government cannot directly control the market. However, the occurrence of market failures should be realized. Moreover, necessary incentives should be offered. The President's Information Technology Advisory Committee (2000) supported traditional markets in underserved communities and encouraged communities to form models for participation in information age business. However, it is unlikely that there will be responses or policies in this area.

In addition, policy developers should consider the macroeconomic model regarding information and communications technology products and services. What efficiently and effectively contributes to equal opportunity should be further discussed. Should everyone obtain a certain product or service at the same price? Should the prices of ICT products and services be weighted by consumers' income? Should policies focus on the benefits for both consumers and producers? These kinds of question would help policy makers to create implacable and tangible goals and objectives.

\section{Content Divide}

Interestingly, the study by the Children's Partnership (2000) addresses an emerging area of the digital divide, the content divide. The results found four important barriers related to content-based services that underserved groups might not be fully benefited: lack of local information, literacy barrier, language barrier and lack of cultural diversity. The report also recommends strategies to overcome these barriers, mostly by focusing on community-based activities. Therefore, encouraging Americans to be quality producers of informa- 
tion, not only consumers, is essential to what is underpinning the content divide, as mentioned in A Nation of Opportunity report (U.S. Advisory Council on the National Information Infrastructure 1996). Such regulations and policies may need to expand their scope to support the underserved groups as producers, including reconsidering digital literacy (both technical competency and information literacy).

\section{Conclusion}

As we can see, the policies regarding the digital divide are not isolated issues, but contain multiple layers from different perspectives. At the forefront of the information age, the United States has been active in closing the digital divide. However, since the development of information and communications technologies is dynamic, the edge of the gaps may be continually widening. To continue to solve the problems of the digital divide, it is the role of government and other sectors to constantly monitor and respond to these changes.

\section{Acknowledgement}

The author would like to thank Toni Carbo for giving valuable comments.

\section{References}

Association of College and Research Libraries. 1989. Presidential Committee on Information Literacy: Final report. URL: http://www.ala.org/ala/acrl/acrlpubs/ whitepapers/presidential.htm [viewed December 9, 2004].

Association of College and Research Libraries. 2000. Information literacy competency standards for higher education. URL: http://www.ala.org/ala/acrl/ acrlstandards/informationliteracycompetency.htm [viewed November 11, 2004].

Bell, P., P. Reddy and L. Rainie. 2004. Rural Areas and the Internet. URL: http://www.pewinternet.org/pdfs/ PIP_Rural_Report.pdf [viewed November 11, 2004].

Bertot, J.C. and C.R. McClure. 2002. Public libraries and the Internet 2002: Internet connectivity and networked services. URL: http://www.ii.fsu.edu/Projects/ 2002pli/2002.plinternet.study.pdf [viewed November 11, 200].
Bill \& Melinda Gates Foundation. 2003. Responding to the needs of other. Bill \& Melinda Gates Foundation Annual Report, 2003. URL: http:// www.gatesfoundation.org/nr/public/media/ annualreports/annualreport03/2003_Gates-AR.pdf [viewed December 9, 2004].

Bush, G.W. n.d. The importance of E-Government. URL: http://www.whitehouse.gov/omb/egov/pres_ memo.htm [viewed November 11, 2004].

Children's Partnership. 2003. The search for high-quality online content for low-income and underserved communities: Evaluating and producing what's need. URL: http://www.contentbank.org/research/Quality Content.pdf [viewed November 11, 2004].

Compaine, B.M. ed. 2001. The digital divide: Facing a crisis or creating a myth? Cambridge, Mass.: MIT Press.

Computers for Youth. 2004. URL: http://www.cfy.org/ about.html [viewed November 11, 2004].

Cooper, M. and G. Kimmelman. 1999. The digital divide confronts the Telecommunications Act of 1996: Economic reality versus public policy. Washington, DC: Consumer Federation of America and Consumers Union.

Digital Divide Network. 2004. About the Digital Divide Network. URL: http://www.digitaldividenetwork. org/content/sections/about.cfm [viewed November 30, 2004].

Education and Library Network Coalition. 2000a. Get the facts. URL: http://www.edlinc.org/get_facts. html [viewed November 11, 2004].

Education and Library Network Coalition. 2000b. Keeping the promise to connect kids and communities to the future. URL: http://www.edlinc.org/keeping_the promise.html\#Community [viewed November 11, 2004].

E-Rate Implementation Working Group. 1997. Report to the Federal Communications Commission (FCC]. URL: http: / / www.ed.gov/Technology/eraterpt.html [viewed November 11, 2004].

Fox, S. 2001. Wired Seniors. URL: http://www. pewinternet.org/pdfs/PIP_Wired_Seniors_Report. pdf [viewed December 9, 2004].

Fox, S. 2004. Older Americans and the Internet. URL: http:/ / www.pewinternet.org/pdfs/PIP_Seniors_ Online_2004.pdf [viewed December 9, 2004].

Federal Communications Commission. 2004. Universal Service. URL: http://www.fcc.gov/wcb/universal_ service/welcome.html [viewed November 10, 2004].

Harwood, P. and L. Rainie. 2004. Use of the Internet in places other than home or work. URL: http:// www.pewinternet.org/pdfs/PIP_Other_Places.pdf [viewed November 30, 2004].

Holzer, H. 1996. What employers want: Job prospects for less educated workers. New York: Russell Sage Foundation.

Jones, S., and M. Madden. 2002. The Internet goes to college. URL: http://www.pewinternet.org/pdfs/ 
PIP_College_Report.pdf [viewed November 11, 2004].

Lacey, M. 2001. Clinton enlists help for plan to increase computer use. In B. M. Compaine, ed., The Digital Divide: Facing a Crisis or Creating a Myth? Cambridge: MIT Press: 263-264.

Lenhart, A., J. Horrigan, L. Rainie, K. Allen, A. Boyce, M. Madden and E. O'Grady. 2003. The ever-shifting Internet population: A new look at Internet access and the digital divide. URL: http://www.pewinternet.org/ pdfs/PIP_Shifting_Net_Pop_Report.pdf [viewed November 11, 2004].

Lenhart, A., L. Rainie and O. Lewis. 2001. Teenage life online. URL: http://www.pewinternet.org/pdfs/ PIP_Teens_Report.pdf [viewed November 11, 2004].

Madden, M. and L. Rainie. 2004. America's online pursuits. URL: http://www.pewinternet.org/pdfs/ PIP_Online_Pursuits_Final.PDF [viewed November 11, 2004].

Mossberger, K., C.J. Tolbert, and M. Stansbury. 2003. Virtual inequality: Beyond the digital divide. Washington, DC: Georgetown University Press.

National Library of Medicine. 1994. Applied research relevant to an electronic medical record. NIH Guide, 23(5). URL: http://grants2.nih.gov/grants/guide/ rfa-files/RFA-LM-94-002.html [viewed November 11, 2004].

National Science Foundation. Advanced Networking Project with Minority-Serving Institutions. 2004. AN-MSI frequently asked questions. URL: http:// www.anmsi.org/faq/faq.asp?Code=AN-MSI [viewed November 30, 2004].

Norris, P. 2001. Digital divide: Civic engagement, information poverty, and the Internet worldwide. Cambridge, UK: Cambridge University Press.

Organisation for Economic Co-operation and Development. 2000. Leaning to bridge the digital divide. Paris: OECD Publications.

Penuel, W.R., C. Korbak, M. Daniels, D. Kim, L. Yarnall, J. Hawkins and R. Pacpaco. 2000. Community technology centers program findings summary: A review of FY99 grantees' annual performance report. Menlo Park, CA: SRI International

Parker, E.B. 2000. Closing the digital divide in rural America. Telecommunications Policy 24: 281-290.

President's Information Technology Advisory Committee. 2000. Resolving the digital divide: Information, access, and opportunity. URL: http://www.itrd.gov/pubs/ pitac/digital_divide/pres-2feb00-ddfinrep.pdf [viewed November 11, 2004].

Rainie, L. 2004. Use of the Internet in places other than home or work. URL: http://www.pewinternet.org/pdfs/ PIP_Other_Places.pdf [viewed November 11, 2004].

Sandvig, C. 2001. Unexpected Outcomes in Digital Divide Policy: What Children Really Do in the Public Library. In B.M. Compaine and S. Greenstein, eds.,
Communications Policy in Transition: The Internet and Beyond. Cambridge, MA: MIT Press: 265-293

Spooner, T. 2001. Asian-Americans and the Internet. URL: http:/ / www.pewinternet.org/pdfs /PIP_Asians_ Report.pdf [viewed November 11, 2004].

Spooner, T. 2003. Internet use by region in the U.S. URL: http:/ / www.pewinternet.org/pdfs/PIP_Regional_ Report_Aug_2003.pdf [viewed November 11, 2004].

Spooner, T. and L. Rainie. 2000. African-Americans and the Internet. URL: http://www.pewinternet.org/ pdfs/PIP_African_Americans_Report.pdf [viewed November 11, 2004].

Spooner, T. and L. Rainie. 2001. Hispanics and the Internet. URL: http://www.pewinternet.org/pdfs/PIP_ Hispanics_Online_Report.pdf [viewed November 11, 2004].

Thompson, S. 2003. Information literacy meeting of experts. URL: http://www.nclis.gov/libinter/ infolitconf\&meet/post-infolitconf\&meet / FinalReportPrague.pdf [viewed November 30, 2004].

Toward equality of access. 2004. UL: http://www. imls.gov/pubs/pdf/Equality.pdf [viewed November 11, 2004].

U.S. Department of Commerce. 2003. Education and training for the information technology workforce. URL: http:/ / www.technology.gov/reports/ITWork Force/ITWF2003.pdf [viewed November 11, 2004].

U.S. Department of Commerce. National Telecommunications and Information Administration. 1995. Falling through the net: A survey of the "have nots" in rural and urban America. URL: http:/ / www.ntia.doc.gov / ntiahome/fallingthru.html [viewed November 10, 2004].

U.S. Department of Commerce. National Telecommunications and Information Administration. 1999. Falling through the net: Defining the digital divide. URL: http://www.ntia.doc.gov/ntiahome/digitaldivide/ [viewed November 11, 2004].

U.S. Department of Commerce. National Telecommunications and Information Administration. 2000. Falling through the net: Toward digital inclusion. URL: http:/ / www.ntia.doc.gov/ntiahome/fttn00/ contents00.html [viewed November 11, 2004].

U.S. Department of Commerce. National Telecommunications and Information Administration. 2002. A Nation Online: How Americans are expanding their use of the Internet. URL: http:/ / www.ntia.doc.gov / ntiahome/dn/ [viewed December 9, 2004].

U.S. Department of Commerce. Office of Technology Policy. 1999. The digital work force: Building infotech skills at the speed of information. URL: http:// www.technology.gov / Reports / itsw / digital.pdf [viewed November 11, 2004].

U.S. Department of Education. 2004. Preparing Tomorrow's Teachers to Use Technology Program. URL: http:/ / 
www.ed.gov/programs/teachtech/index.html [viewed November 11, 2004].

U.S. Department of Education. Office of Educational Technology. 2000. E-rate factsheet. URL: http:// www.ed.gov/Technology/comm-mit.html [viewed November 11, 2004].

U.S. Department of Education. Planning and Evaluation Service. 2000. E-rate and the digital divide: A preliminary analysis from the integrated studies of educational technology. Washington, DC: Urban Institute. URL:http://www.urban.org/pdfs/erate_FR921.pdf [viewed November 11, 2004].

U.S. White House. 2000. The Clinton-Gore administration: From digital divide to digital opportunity. URL: http:/ / clinton4.nara.gov/WH/New/digitaldivide/ digital1.html [viewed November 11, 2004)

U.S. White House. n.d. From digital divide to digital opportunity: A Strong record of working to close the digital divide. URL: http://clinton4.nara.gov/textonly/WH/ New/digitaldivide/digital4.html [viewed November 11, 2004].

U.S. White House. Office of the Press Secretary. 2000. From digital divide to digital opportunity: A national call to action. URL: http://clinton4.nara.gov/WH/ New/html/20000404_1.html [viewed November 11, 2004].

U.S. White House. Office of the Vice President. 1998. Digital divide events. URL: http:/ / clinton3.nara.gov / WH/EOP/OVP/speeches/edtech.html [viewed November 11, 2004].

United States Advisory Council on the National Information Infrastructure. 1996. A nation of opportunity: Realizing the promise of the information superhighway. Washington, DC.

United States Embassy, Tokyo, Japan. 2000. Clinton joins G-8 in creation of digital opportunity task force. URL: http://japan.usembassy.gov/e/o/tp-g067.html [viewed November 11, 2004].

Weller, D. 1999. Auctions for universal service obligations. Telecommunication Policy 23: 645-674.

Wilhelm, A.G. 2004. Digital nation: Toward an inclusive information society. Cambridge, Mass.: MIT Press.

Wilhelm, T., D. Carmen and M. Reynolds. 2002. Connecting kids to technology: Challenges and opportunities. URL: http:/ / www.aecf.org/publications/data/ snapshot_june2002.pdf [viewed November 11, 2004].

Editorial history:

paper received 14 April 2006;

accepted 12 September 2006. 